\title{
Evaluation of Free Radicals and Some Other Biochemical Parameters in Leukemia and B-Thalassemia in Erbil City
}

\author{
Pshtiwan Abdulla Yousif, Parween Abdulsamad Ismail* and Avein Fhaithwlla \\ Department of Chemistry, Education College, University of Salahaddin, Iraq \\ *Corresponding author: Parween Abdulsamad Ismail, Department of Chemistry/Education College, University of Salahaddin, Erbil, \\ Iraq
}

\begin{abstract}
Background: Free radicals have been shown to be involved in the etiology of degenerative diseases, and medical conditions such as heart disease, cancer and ageing. Various biochemical markers are indicators of pathological state in both thalassimia and leukemia. Increased oxidative stress and decreased antioxidant factors play a key role in the pathogensis of both diseases. High ROS production has been associated with significant decrease in antioxidant defense mechanisms leading to protein, lipid and DNA damage.
\end{abstract}

Aim: To conduct comparative analysis of MDA and as a marker of oxidative stress in patients with $\beta$-thalassimia and leukemia.

Materials and methods: This research work was conducted on a total number of 95 subjects in which 20 were control participants and 75 patients (35males and 40 females) mean age (59.2 \pm 3.5 years) The levels of serum lipids, MDA, total Sialic acid, catalase and total protein, were measured in all participants.

Results: In both groups of patients $\beta$-thalassimia and leukemia Serum MDA and total Sialic acid levels were significantly higher when compared to the controls $(\mathrm{p}<0.001)$. The results showed significant decrease $(\mathrm{p}<0.001)$ in Catalase activity of thalassemic and leukemic patients in comparing with healthy control group. No significant differences were observed in the comparison of total protein levels between patients' group and healthy control group.

Conclusion: Oxidative stress is involved in pathogensis of of thalassemia and leukemia, as evident from elevated malondialdehyde levels and decreased catalase activity. Elevated levels of sialic acid andtotal proteins suggest the role of glycoproteins in carcinogenesis proceses.

Keywords: Free radicals; Leukemia; $\beta$-Thalassemia

\section{Introduction}

Free radical production occurs continuously in all cells as part of normal cellular function. However, excess free radical production originating from endogenous or exogenous sources might play a role in many diseases. Free radicals are implicated in the pathogenesis of multi-stage process of carcinogenesis. They are proposed to cause DNA base alterations, strand breaks, damage to tumor suppressor genes and enhanced expression of proto-oncogenes [1-4]. lipid hydroperoxide, malondialdehyde, and decreased blood levels of antioxidants catalase, superoxide have been reported in cancer patients. Antioxidants prevent free radical induced tissue damage by preventing the formation of radicals, scavenging them, or by promoting their decomposition [5] Thalassemia major can result in severe complications and even death due to absence of hemoglobin A synthesis and the patients are more dependent on transfusion of blood [6]. Iron metabolism disorders are common in the human including both iron deficiency anemia and excessive iron storage. Iron is essential for oxidation-reduction catalysis and bioenergetics, but unless appropriately shielded, iron plays a key role in the formation of toxic oxygen radicals that can attack all biological molecules. Hence, specialized molecules for the acquisition, transport (transferrin), and storage (ferritin) of iron in a soluble nontoxic form have evolved [7] Reactive oxygen species (ROS) degrade polyunsaturated lipids, forming malondialdehyde that mainlyexists in the enol form [8]. This compound is one of the many reactive electrophile species that cause toxic stress in cells and form covalent protein adducts which are referred to as advanced lipoxidation end products [9]. The effect of OS to the cells may either be acute or chronic. Chronic OS results from little 
oxidative damage which accumulates during the life cycle of the cell and subsequently disrupts essential cellular functions and triggers many cancers [10-12], including solid tumors such as prostate carcinoma melanoma [13], and several hematopoietic malignancies such as acute lymphoblastic leukemia (ALL),[14] myelodysplastic syndrome (MDS), [14] and myeloid leukemia; chronic myeloid leukemia (CML) and acute myeloid leukemia (AML) $[15,16]$. The objective of our study was to measure the intensity of oxidative damage at the cellular and molecular levels through measurements of lipid peroxidation and protein carbonyls. The study also aimed to investigate the oxidative profile in CML patients through the verification of main enzymatic antioxidant defenses (catalase [CAT] and superoxide dismutase [SOD]), nonenzymatic antioxidants (vitamins A and E), and essential micronutrients (selenium, magnesium, and zinc) in the blood of CML patients.

\section{Materials and Methods}

\section{Subjects}

The study subjects consisted of 32 clinically diagnosed CML patients and 32 clinically diagnosed $\beta$-thalassemia major at Nanakaly hospital in Erbil. patient. The controls consisted of 32age- and sex matched healthy volunteers. The control subjects were selected from healthy subjects, and their clinical blood profiles were within the normal range, and the general health status was normal.

\section{Blood sample}

Blood from thalassemic, Leukemic patients and controls was collected, the samples were centrifuged at $3000 \mathrm{rpm}$ for $10 \mathrm{~min}$ to separate serum. The separated serum was collected for further analysis in polythene tube with cork and stored at $-200 \mathrm{C}$.

\section{Biochemical Analyses}

\section{a) Determination of Malondialdehyde (MAD) level}

Serum Malondialdehyde level was determined by a spectrophotometric method using the Randox assay kit the principle of method based on reaction with thiobarbituric acid (TBA) at $90-100^{\circ} \mathrm{C}(18)$. MDA and TBA react together in the TBA test reaction, to produce a pink pigment having an absorption maximum at $532 \mathrm{~nm}$. The reaction was performed at $\mathrm{pH} 2-3$ at $90^{\circ} \mathrm{C}$ for 15 minutes.

\section{b) Determination the activity of catalase}

catalase activity was assayed by by a spectrophotometric method using the Randox assay kit the principle of method based on the utilization of $\mathrm{H} 2 \mathrm{O} 2$ by the enzyme. The color developed was read at $620 \mathrm{~nm}$.

\section{c) Determination of Sialic acid level}

Measurement of Sialic acid based on reaction of sialic acid with acid ninhydrin reagent. The absorbance of colored product was measured at $470 \mathrm{~nm}$.

\section{d) Determination of Total protein level}

Total, protein Total protein was measured using a colorimetric kit based on the biuret method.

\section{e) Biostatistical analysis}

Statistical analyses were performed with the SPSS 10.0 pocket programme for Windows (SPSS Inc., Chicago, IL, USA). The data were expressed as mean values \pm standard deviation $(X \pm \mathrm{SD})$. The level of statistical significance was defined as $P<0.05$ (Table 1 ).

Table 1: Comparsion of Serum MDA levels between control and patients group.

\begin{tabular}{|c|c|c|c|}
\hline Parameters & leukemia & Thalassemia & P-Value \\
\hline $\mathrm{MDA}(\mathrm{nmol} / \mathrm{ml})$ & $4.476 \pm 3.08$ & $4.940 \pm 1.19$ & $\mathrm{p}<0.001$ \\
\hline
\end{tabular}

\section{Results}

As presented in Figure 1 The mean level of MDA was significantly higher in CML cases $(4.476 \pm 3.08 \mathrm{nmol} / \mathrm{ml})$ as compared to control cases $((1.59 \pm 0.28 \mathrm{nmol} / \mathrm{ml})$. The elevated levels of MDA in patients are a marker of increased oxidative stress, Also The level of MDA as depicted in Figure(2), was increased highly significant $(\mathrm{p}<0.001)$ in $\beta$ - thalassemic patients $(4.940 \pm 1.19 \mathrm{nmol} /$ $\mathrm{ml})$ in comparasion to healthy control $(1.59 \pm 0.28 \mathrm{nmol} / \mathrm{ml})$, Table 2 shows the status of Catalase activity, total Sialic Acid (TSA) and Total Proteins In controls, Thalassemic and leukemic subjects. The activitiy of catalase, was significantly decreased in both Thalassemic $(24 \pm 22.5(\mathrm{KU} / \mathrm{L})$ and leukemic patients $(26.25 \pm 24$ $\mathrm{KU} / \mathrm{L}$ ) (as compared to control subjects $(205.36 \pm 41.83 \mathrm{KU} / \mathrm{L}$ ). The serum TSA level was significantly increased both Thalassemic $(64.25 \pm 4.33 \mu \mathrm{g} / \mathrm{mL})$ and leukemic patients $(79.60 \pm 6.93 \mu \mathrm{g} / \mathrm{mL})$ as compared to control subjects $(51.60 \pm 3.51 \mu \mathrm{g} / \mathrm{mL})$. Significant difference was obtained for serum Total Proteins levels between patients and control.

Table 2: The results of main biochemical parameters in healthy control and patients group.

\begin{tabular}{|c|c|c|c|c|}
\hline Parameters & $\begin{array}{c}\text { Healthy } \\
\text { Control }\end{array}$ & leukemia & Thalassemia & P-value \\
\hline $\begin{array}{c}\text { Catalase } \\
(\mathrm{KU} / \mathrm{L})\end{array}$ & $\begin{array}{c}205.36 \pm \\
41.83\end{array}$ & $\begin{array}{c}26.25 \pm \\
24\end{array}$ & $.24 \pm 22.5$ & $<0.001$ \\
\hline $\begin{array}{c}\text { TSA }(\mu \mathrm{g} / \\
\mathrm{mL})\end{array}$ & $\begin{array}{c}51.60 \pm \\
3.51\end{array}$ & $\begin{array}{c}79.60 \pm \\
6.93\end{array}$ & $64.25 \pm 4.33$ & $<0.001$ \\
\hline Total & $8.17 \pm$ & $12.01 \pm$ & $14.01 \pm 1.05$ & $<0.05$ \\
Proteins & 0.29 & 0.95 & & \\
\hline
\end{tabular}




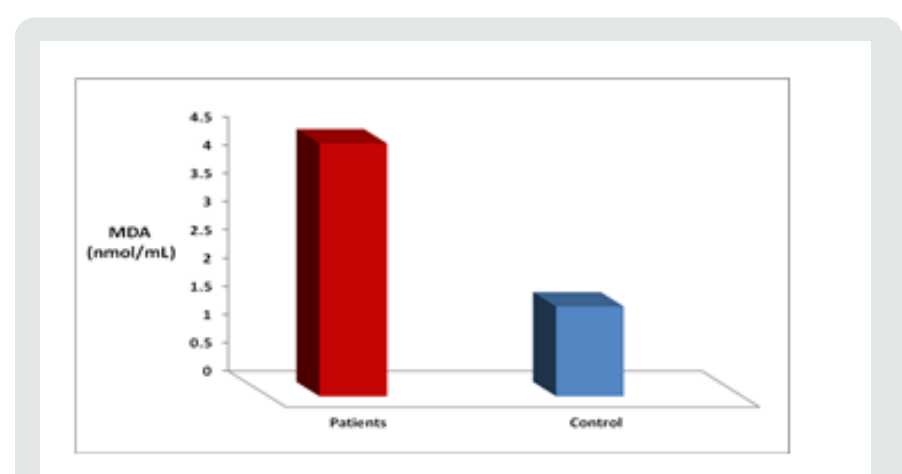

Figure 1: Mean Serum levels of MDA in leukemic patients group and healthy control

\section{Discussion}

Presentstudy revealed elevated malondialdehyde concentration in Thalassemic patients indicating increased lipid peroxidation. The oxidative stress causes lipid peroxidation to generate wide range of products including MDA. Previous investigations demonstrated that malondialdehyde plays important roles in the processes of carcinogenesis through their interaction with DNA and formation of DNA-MDA adduct. This DNA-MDA adducts induce mutations in various genes such as tumor suppressor genes and oncogens as well as cell cycle alterations in different cancers [17]. Elevated levels of lipid peroxidation along side decreased concentrations of antioxidant capacity have been severally reported in patients with head and neck cancers $[18,19]$. Elevated levels of lipid peroxidation and MDA are largely linked to the damage of red blood cell membranes enriched by polyunsaturated fatty acids. The concentrations of free radicals increase in different cancers leading to enhanced lipid peroxidation. On the other hands, the levels of antioxidant capacity decreased following enhancement of ROS production in compensatory manner [20]. MDA is a good biomarker of oxidative damage. The extent of lipid peroxidation denotes the amount of free oxygen radicals generated, which have not been eliminated by the defense mechanism. There are increasing evidences proposing that oxidative stress is a major damaging factor. This is due to the effect of continuous blood transfusions in these patients which leads to peroxidative tissue injury by the secondary iron overload. Absence of beta globin chains lead to accumulation of unpaired alpha globin chains. Excess presence of the alpha globin chains is a primary reason for the cellular oxidative damage and also iron overload. As a result of both high plasma iron and high intracellular non hemoglobin iron in beta thalassemia, there is an enhanced generation of ROS [21,22]. Moreover, repeated blood transfusion causes iron overload which increases free radical formation and peroxidative damage of tissues. In such condition, depletion of endogenous antioxidants may be expected. Peroxidative damage of lipids was indicated by the increase in serum MDA levels following oxidation of polyunsaturated fatty acids [23].

In the Present study Figure 2, we found that the concentration of malondialdehyde was increased in leukemic patients when compared to healthy controls. Free radicals play an important role in the pathophysiology of myeloid leukemia, and that high levels of free radicals may cause oxidative stress in haematopoietic cells if the antioxidant defense system is not potential. Oxidative stress may occur in patients with leukemia due to the higher number of mature and immature myeloid series cells as well as other unknown factors. Malondialdehyde (MDA) which is a stable end product of free radical induced-lipid peroxidation was used as a surrogate marker for oxidative damage to tissues. Anti-oxidants, which control the oxidative stress state, represent a major line of defense regulating overall true state of health. The disturbance of the pro-oxidant/antioxidant balance, resulting from elevated freeradical production, antioxidant enzyme inactivation, and excessive antioxidant consumption, is the causative factor in oxidative damage. These free radicals set up a chain reaction that changes cell permeability, denatures proteins, alters enzyme activity, decreases neurotransmitter transmission, causes breakage of DNA, and degrades structural proteins. Thus, free radicals are directly responsible for causing genetic mutations and carcinogenesis.

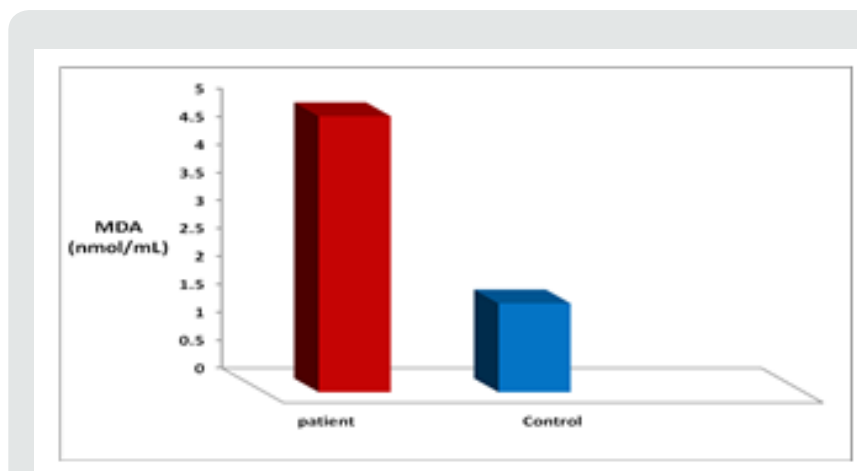

Figure 2: Mean Serum levels of MDA in Thalassemic patients' group and healthy control

In our study, we found that the activity of Catalase was decreased in leukemic and Thalassemic patients when compared to healthy controls. Catalase activity in patients with $\beta$-thalassemia major is decreased as compared to normal healthy control Decrease in the activity of CAT could be due to increase in the lipid peroxidation product, malondialdehyde which can form cross links, there by in activating several membranes bound enzymes. The body has multiple defense mechanisms against free radical-mediated tissue damage. Among them, antioxidants are the primary lines of defense. Under normal circumstances, there is a critical balance between pro-oxidizing and antioxidizing forces. Antioxidants interact with free radicals in several Cancer cells under sustained ROS stress tend to heavily utilize adaptation mechanisms and may exhaust cellular ROS-buffering capacity. A relationship between leukemia and oxidative stress has been observed. Leukemic cells produce higher amounts of ROS than nonleukemic cells because the former are experiencing sustained oxidative blockade [24].

The current study shows that the total Sialic Acid (TSA) levels were significantly increased in patients group. Serum TSA 
has also been used as a tumor marker for a number of different cancers including colorectal, prostate, and breast cancers [25,26]. Cell surfaces and membrane components play a prominent role in neoplastic behavior. Neoplasms often have an increased concentration of TSA on the tumor cell surface, and sialo glycoproteins are shed or secreted by some of these cells, which increases the concentration in blood .Moreover, cancer cells have been associated with an increased activity of sialytransferase , leading to an increased amount of TSA on the cell surface, thus increasing the plasma or salivary concentration [27,28]. TSA concentrations have been reported to be related not only to diagnosis, but also to staging, prognosis, and detection of early recurrence. It has been suggested that evaluations of the serum glycoconjugate levels may be useful in early detection and staging of oral precancerous conditions and oral cancer [29].

\section{Conclusion}

It may be concluded from the finding of the study that accumulation of free radicals contributes to antioxidant depletion and dysfunction in both Thalassemic and leukemic patients. high levels of serum malondialdehyde with poor antioxidant level indicates that oxidative stress may be a major cause for the pathogensis of beta thalassemia and leukemia.

\section{References}

1. Cerutti PA (1994) Oxy-radicals and cancer. Lancett 344: 862-863.

2. Gonalez RA (1999) Free radicals, oxidative stress and DNA metabolism in human cancer. Cancer Invest 17: 376-377

3. Irshad M, Chaudhuri PS (2002) Oxidants, antioxidants and carcinogenesis. Indian J Exp Biol 40: 1213-1232.

4. Patel BP, Rawal UM, Raval RM, Shukla SN, Patel PS (2008) Tobacco, antioxidant enzymes, oxidative stress and ge-netic susceptibility in oral cancer. Am J Clin Oncol 31: 454-459.

5. Young IS (2001) Woodside JV Clin Pathol. 54: 176-186.

6. Cunningham MJ (2008) Update on thalassemia: clinical care and complications. Pediatr Clin North Am 55(2): 447-460.

7. Ponka P (2003) Recent advances in cellular iron metabolism. Article first published online: J Trace Elem Exp Med 16: 201-217.

8. Nair CL O’Neil, PG Wang (2008) "Malondialdehyde" Encyclopedia of Reagents for Organic Synthesis, John Wiley \& Sons, Article Online Posting, New York, USA.

9. Farmer EE, Davoine C (2009) Reactive electrophile species. Curr Opin Plant regulates cancer. Cell Mol Life Sci 66: 3663-3673.

10. Lau AT, Wang Y, Chiu JF (2008) Reactive oxygen species: current knowledge and applications in cancer research and therapeutic. J Cell Biochem 104: 657-667.

11. Renschler MF (2004) The emerging role of reactive oxygen species in cancer therapy. Eur J Cancer 40:1934-1940.

12. Kumar B, Koul S, Khandrika L, Meacham RB, Koul HK (2008) Oxidative stress is inherent in prostate cancer cells and is required for aggressive phenotype. Cancer Res 68: 1777-1785.

13. Fried L, Arbiser JL (2008) The reactive oxygen-driven tumor: relevance to melanoma. Pigment Cell Melanoma Res 21: 117-122.

14. Battisti V, Maders LD, Bagatini MD, Santos KF, Spanevello RM, et al. (2008) Measurement of oxidative stress and antioxidant status in acute lymphoblastic leukemia patients. Clin Biochem 41: 511-518.

15. Farquhar MJ, Bowen DT (2003) Oxidative stress and the myelodysplastic syndromes. Int J Hematol 77: 342-350.

16. Sallmyr A, Fan J, Rassool FV (2008) Genomic instability in myeloid malignancies: increased reactive oxygen species (ROS), DNA double strand breaks (DSBs) and error-prone repair. Cancer Lett 270: 1-9.

17. Blair IA (2008) DNA adducts with lipid peroxidation products. J Biol Chem 283(23): 15545-15549.

18. Rasheed MH, Beevi SS, Geetha A (2007) Enhanced lipid peroxidation and nitric oxide products with deranged antioxidant status in patients with head and neck squamous cell carcinoma. Oral Oncol 43(4):333-338.

19. Halliwell B (2007) Oxidative stress and cancer: have we moved forward? Biochem J 401(1):1-11.

20. Malathi M, Vijay M, Shivashankara AR (2011) The role of oxidative stress and the effect of radiotherapy on the plasma oxidant-antioxidant status in head and neck cancer. J Clin Diagnos Res 5(2): 249-251.

21. Ghone RA, Kumbar KM, Suryakar AN (2008) Oxidative stress and disturbance in antioxidant balance in beta thalassemia major. Ind J Clini Biochem 23: 337-340.

22. Kassab Chekir A, Laradi S, Ferchichi S, Haj Khelil A, Feki M, et al. (2003) Oxidant, antioxidant status and metabolic data in patients with betathalassemia. Clin Chim Acta 338(1-2): 79-86.

23. Kalpravidh RW, Siritanaratkul N, Insain P, Charoensakdi R (2010) Improvement in oxidative stress and antioxidant parameters in beta-thalassemia/Hb E patients treated with curcuminoids. Clinical Biochemistry 43: 424-429.

24. Al Gayyar MM, Eissa LA, Rabie AM, El Gayar AM (2007) Measurements of oxidative stress status and antioxidant activity in chronic leukemia patients. J Pharm Pharmacol 59(3): 409-417.

25. Erbil KM, Jones JD, Klee GG (1985) Use and limitations of serum total and lipid-bound sialic acid concentrations as markers for colorectal cancer. Cancer 55(2): 404-409.

26. Plucinsky MC, Riley WM, Prorok JJ, Alhadeff JA (1986) Total and lipidassociated serum sialic acid levels in cancer patients with different primary sites and differing degrees of metastatic involvement. Cancer 58(12): 2680-2685.

27. Sillanaukee P, Pönniö M, Jääskeläinen IP (1999) Occurrence of sialic acids in healthy humans and different disorders. European Journal of Clinical Investigation 29(5): 413-425.

28. Sata T, Roth J, Zuber C, Stamm B, Heitz PU (1991) Expression of alpha 2,6-linked sialic acid residues in neoplastic but not in normal human colonic mucosa: a lectingold cytochemical study with Sambucus nigra and Maackia amurensis lectins. The American Journal of Pathology 139(6): 1435-1448.

29. Baxi BR, Patel PS, Adhvaryu SG, Dayal PK (1991) Usefulness of serum glycoconjugates in precancerous and cancerous diseases of the oral cavity. Cancer 67(1): 135-140. 
(C) This work is licensed under Creative

To Submit Your Article Click Here: Submit Article

DOI: $10.32474 /$ RRHOAJ.2019.04.000189

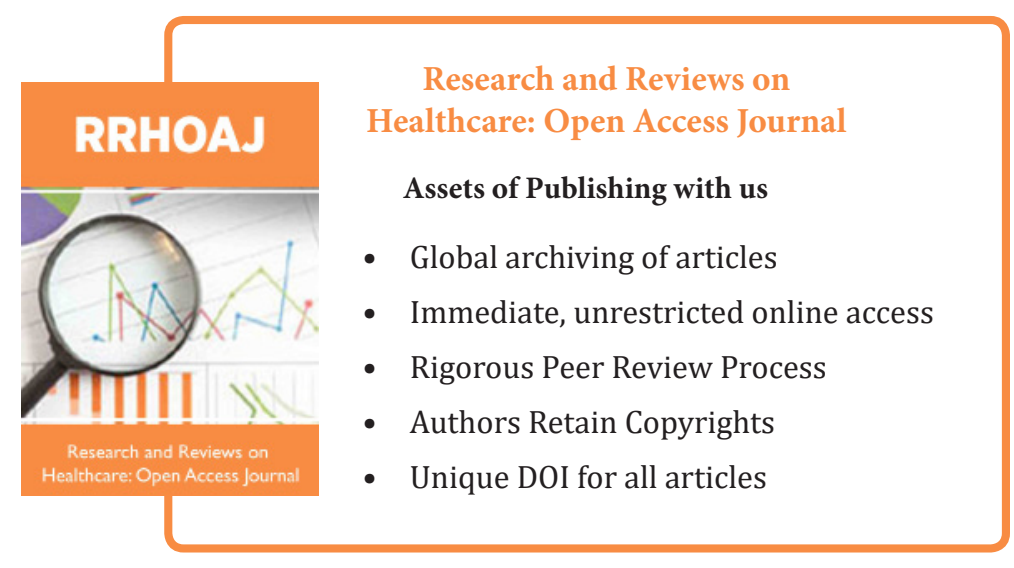

